IZA DP No. 10256

Dynamics in Health and Employment:

Evidence from Indonesia

Subha Mani

Sophie Mitra

Usha Sambamoorthi

October 2016 


\title{
Dynamics in Health and Employment: Evidence from Indonesia
}

\author{
Subha Mani \\ Fordham University, \\ University of Pennsylvania and IZA \\ Sophie Mitra \\ Fordham University \\ Usha Sambamoorthi \\ West Virginia University
}

\section{Discussion Paper No. 10256 \\ October 2016}

\author{
IZA \\ P.O. Box 7240 \\ 53072 Bonn \\ Germany \\ Phone: +49-228-3894-0 \\ Fax: +49-228-3894-180 \\ E-mail: iza@iza.org
}

Any opinions expressed here are those of the author(s) and not those of IZA. Research published in this series may include views on policy, but the institute itself takes no institutional policy positions. The IZA research network is committed to the IZA Guiding Principles of Research Integrity.

The Institute for the Study of Labor (IZA) in Bonn is a local and virtual international research center and a place of communication between science, politics and business. IZA is an independent nonprofit organization supported by Deutsche Post Foundation. The center is associated with the University of Bonn and offers a stimulating research environment through its international network, workshops and conferences, data service, project support, research visits and doctoral program. IZA engages in (i) original and internationally competitive research in all fields of labor economics, (ii) development of policy concepts, and (iii) dissemination of research results and concepts to the interested public.

IZA Discussion Papers often represent preliminary work and are circulated to encourage discussion. Citation of such a paper should account for its provisional character. A revised version may be available directly from the author. 


\section{ABSTRACT}

\section{Dynamics in Health and Employment: Evidence from Indonesia*}

This paper examines the consequences of disability, identifying for the first time, the separate impacts of onsets and recoveries from disability on both employment status and hours worked using panel data from Indonesia. We find that changes in physical functioning have no affect hours worked among the employed. However, we find that onsets of physical limitations lead to an increase in the probability of leaving employment, while recoveries increase the probability of returning to work. We also find a larger effect among selfemployed workers compared to salaried workers. These results overall point towards a need for social protection policies with a focus on health, disability, and employment in Indonesia.

\section{JEL Classification: $\quad 112, \mathrm{~J} 32, \mathrm{~J} 24$}

Keywords: health, disability, aging, employment, hours worked, Indonesia

Corresponding author:

Subha Mani

Department of Economics

Fordham University

441 East Fordham Road

Dealy Hall, E 520

Bronx, New York 10458

USA

E-mail: smani@fordham.edu

\footnotetext{
* We are grateful for insightful comments from session participants at the 2013 Association of Public Policy And Management (APPAM) Annual Meeting, the 2013 Population Association of America Annual Meeting, and seminars at Fordham University, University of Kwazulu Natal, and the Japan International Economic Agency Research Institute. The usual disclaimer applies.
} 


\section{Introduction}

The proposition that health in general, and disability in particular, may affect employment seems reasonable, if not obvious (Bowen and Finegan 1969; Currie and Madrian 2000). There is much evidence on the impact of health shocks on lost productivity and wages in low- and middleincome countries (LMICs) (e.g., Alderman, Behrman, Hoddinott (2005); Rivera B, Currais (2005); Thomas and Strauss (1997); Thomas et al (2006)). However, the negative impact of health shocks on labor force participation and hours worked is only documented in high-income countries (e.g., Cai, Mavromaras, Oguzoglu (2014); García Gómez, López Nicolás (2006)). In addition, while disability has been associated with multidimensional poverty in LMICs (Mitra et al 2013; Trani et al $(2015 ; 2016))$, the negative correlation between disability and employment has not been systematically found (Mizunoya et al 2013). It is possible that some labor markets in developing countries have more flexibility and fluidity that make it possible to stay or return to work following a health shock or disability onset.

Assessing the effects of health and disability on labor market outcomes (employment and hours worked) in LMICs remains important for several reasons. First, there is evidence of an epidemiological transition in terms of declining mortality and increasing morbidity (Shrestra 2000). With longer lives comes increasing prevalence of chronic health conditions, the number of years in a working life with health problems and disability is on the rise, and the economic consequences of disability onsets with causal interpretation remain limited. Second, increase in the incidence of disability with aging also comes with substantial transitions in disability with individuals reporting both onsets and recoveries over time. Consequently making it important to separate out the causal effects of both disability onsets and recoveries on labor market outcomes. Third, few individuals and households are formally insured against health shocks whether through health insurance, sick leave or disability insurance. Therefore, the link between health, disability, and labor market outcomes is of increasing policy relevance. 
This paper addresses several questions on the dynamics of disability and labor market outcomes that have received limited attention in LMICs. First, how prevalent are physical disabilities and recoveries. Second, how do individuals adjust their employment status and hours worked to a physical disability? Third, what is the impact of recovery on employment and hours worked? To examine these questions we use a unique panel dataset following working age adults for 14 years through four waves of the Indonesian Family Life Survey (IFLS) separately identifying for the first time, the causal effects of onsets of disability and recoveries on labor market outcomes. We use a variety of measures of disability measured in terms of physical functioning. This paper also addresses the endogeneity of disability using a first difference (FD) and first difference instrumental variable (FD-IV) estimation strategies.

A handful of studies in LMICs that attempt to analyze the relationship between disability and labor market outcomes have produced mixed findings. Five of the six studies on the impact of health decrement on employment status find a negative effect (Gertler and Gruber 2002; Pohl, Neilson and Parro 2013; Schultz 2008). Three of the five studies that examine the impact of health decrements and disability find a negative impact on hours worked (Schultz and Tansel 1997; Mete, Ni and Scott 2008; Schultz 2008; Gertler and Gruber (2002)). Fewer researchers have examined the impact of disability on individual earnings and wages. While Genoni (2012) and Schultz (2008) do not find a significant effect of health decrements on individuals' earnings, Schultz and Tansel (1997) do so.

The body of evidence is mixed partly due to challenges in measuring health and disability and the complex relationships between health and labor market outcomes. Health can be measured with many facets and levels of severity. Another challenge lies in econometrically isolating the causal impact of health on economic outcomes. The relationship between health and labor market outcomes is complex, with positive (e.g. mental health benefits that may come from social networking at work) and negative (e.g., through work-related stress or injuries) relationships. 
Thus, health decrements and disability are not strictly exogenous. Finally, the existing literature makes no distinction between the economic cost of disability onset and the economic gains or recovery associated with recovery form disability.

We construct a unique panel dataset following working age adults for 14 years through four waves of the Indonesian Family Life Survey (IFLS) to separately identify for the first time, the causal effects of both onsets of disability (for a variety of measures) and as well as recoveries from disability on labor market outcomes. Our preferred FD-IV estimates show that onset of physical activity limitations and recovery has implications for job entry and exit, but has no impact on hours worked. Our preferred estimates address both omitted variables bias as well as measurement error bias in physical functioning limitation. Answers to these questions have important policy implications for the design of safety net programs in LMICs.

\section{Background}

In Indonesia, during the period of this study, 1993-2007, unemployment fluctuated from 3.9\% in 1995, to $9.9 \%$ in 2004, and down to $8.4 \%$ in 2008 (World Bank 2015). The Asian Economic Crisis also affected Indonesia in 1996/97, which led not so much to a reduction in employment, but to an increased reliance on self-employment, and to a lesser extent, on farm work (Smith et al 2002). In Indonesia, as in LMICs in general, labor markets are segmented and most employment is found in the informal sector, where people are self-employed or work in microenterprises. The informal sector has commonly been characterized as an "easy-entry sector that workers can enter to earn some cash in preference to earning nothing" (Fields 2005). Fields points that "barriers to entry to such occupations are small or non-existent. In some contexts, primarily urban, all that would-be workers need to do is make a minimal investment in the product or service to be sold." This ease of entry into the informal sector helps explain the relatively low level of unemployment rates in many LMICs, and may facilitate the re-entry into the labor market after a health shock.

During the study period, access to social insurance or protection programs that may address 
the employment consequences of health shocks was limited. In 2008, $17 \%$ of the employed population enjoyed formal social security mainly for employees of the formal sector (ILO 2010). Social security for informal workers, about two-thirds of all workers, was not available (ILO 2010). Social security reform in the country was boosted by the enactment of Republic Law number 40 of 2004 concerning the National Social Security System (SJSN - Sistem Jaminan Sosial Nasional) which established a National Social Security Board charged with making recommendations for the development of new old-age, survivors, health insurance, and work injury programs (ILO 2008). The implementation was delayed and did not come into effect during our study period ${ }^{\mathrm{i}}$.

This study examines the impact of health, and its aim is not to isolate the effects of particular policy reforms. Instead, it focuses on health in the entire working age population. The workingage population is not a target group for social protection purposes in Indonesia and yet is a group whose health status is intuitively most likely to affect the economic welfare of the household.

\section{Data and Measures}

\subsection{Data}

The data used in this paper is a balanced panel that comes from the 1993, 1997, 2000, and 2007 waves of the IFLS, a large-scale socio-economic panel survey conducted in Indonesia. The IFLS collects extensive information at the individual, the household, and the community level. The survey includes modules on health, household composition, consumption expenditure, labor and non-labor income, among others ${ }^{\mathrm{ii}}$. The sample surveyed in 1993/94 represented $83 \%$ of the Indonesian population living in 13 of Indonesia's 27 provinces at the time. Provinces were selected to maximize representation of the population, capture the cultural socio-economic

diversity of Indonesia, and yet be cost-effective given the size and the terrain of the country. A total of 321 communities were selected from these 13 provinces for final survey purposes. 
The IFLS is unique in a number of ways: (1) it links individual, household, and community level data bringing together an enormous amount of information that enables us to better understand the impact of health on individual level employment and hours worked controlling for both observables and unobservables; (2) few other surveys collect data on health over a 14 year period that enables us to examine the effects of both onsets and recoveries from physical activity limitations; (3) the panel data nature of the IFLS is particularly useful for addressing the presence of time-invariant unobservables such as one's own ability to fight diseases and or likelihood of over reporting or under reporting health that are likely to be correlated with the health variable in the regressions which we do through first-differencing.

\subsection{Labor Market Outcomes: Employment and Hours Worked}

We analyze two labor market outcomes for individuals aged 26 to $50^{\mathrm{iii}}$ during the first wave in 1993: employment status and hours worked during the last week. In the IFLS, employment status (employed vs. not employed) is captured through a set of different questions. A person is considered employed if he or she reports that during the past week, he or she was working/trying to work/helping to earn an income, working at a family-owned (farm or nonfarm) business, or having a job but was not working this past week. Besides being salaried or self-employed, individuals may also report a third type of job: unpaid family worker. We did not consider unpaid family worker as being employed.

Individuals report their hours of work during the past week for one or two jobs: their primary job, i.e., the job which consumes the most time, and an additional job, if any. If individuals have one job, the hours of work are that of the primary job. If individuals have two jobs, we add the hours of work for each individual for their two jobs. We use hours of work among the employed across waves. In this study, using hours worked as a continuous indicator of employment, with zero for the unemployed, consistently leads to similar results as using binary 
indicators of employment status or transitions. In this study, we therefore consider two outcomes: (1) employment status for the entire sample and (2) hours of work, conditional on employment ${ }^{\mathrm{iv}}$.

\subsection{Physical Disability Measures}

Health is a complex and multifaceted concept that can be measured in numerous ways (e.g. Stewart and Ware 1992, Schultz and Tansel 1997). In the context of the economic consequences of poor health, any decrement in health may limit how much work a person can do. Studies in LMICs have used several definitions to measure health status (see Currie and Madrian 1999; Strauss and Thomas 1998, 2008 for review). These range from general health status (Dow et al 1997) to morbidity (Gertler and Gruber 2003) and mortality (Grimm 2010). More specifically, in recent papers that examine the relationship between health and employment outcomes, three selfreported indicators of health: normal activity, morbidity, and physical functioning, have received attention.

Lost days of normal activity due to ill-health reflect time allocation decisions, that can be influenced by the wage or other work related factors (e.g. working conditions) and therefore are endogenous. This is especially problematic for the study of individual labor market outcomes, as in this paper. Morbidity is usually captured through self-reported symptoms such as nausea, fever, or cough. Such symptoms sometimes may not reflect major health problems that influence employment. In low-income countries as Strauss and Thomas (1997) note, "it is not unusual for the poorest to appear to be the most healthy by this metric!" (p. 791). Measurement error is also an important concern for self-reported indicators of morbidity. A similar concern applies to questions on chronic health conditions. Furthermore, in a LMIC context, with very limited access to health care, many people may not be aware of their chronic health conditions.

Health problems are also measured by physical functioning limitations, which are sometimes referred to as physical disability. Physical functioning limitations are captured using difficulties in activities of daily living (ADL), such as walking a specific distance or bending. 
There are two types of ADLs: basic and intermediate. Basic ADLs are fundamental for body functioning (e.g. walking) and include self-care activities such as feeding oneself, going to the bathroom without help, and dressing without help. Intermediate ADLs are more complex tasks such as shopping, housekeeping, food preparation. ADLs overall have the advantage to be more specific than the "normal activity" question above and are less likely to suffer from measurement error in morbidity (Dow et al 1997). Intermediate ADLs however include role activities that can be related to the employment outcomes of interest in this study and can be influenced by many factors other than health (Stewart and Ware 1992).

Given the reasons explained above, normal activity and morbidity measures, although available in the IFLS, are not used in this paper. In this paper, we use IFLS' nine questions related to limitations in basic ADLs or physical functioning, which can be considered as measures of physical disability ${ }^{\mathrm{v}}$. The nine questions included in all four waves is as follows: If you had [...] by yourself, could you do it: (1) to carry a heavy load (like a pail of water) for 20 meters; (2) to draw a pail of water from a well; (3) to walk for 5 kilometers; (4) to sweep the house floor yard; (5) to bow, squat, kneel; (6) to dress without help; (7) to go to the bathroom (BM) without help; (8) to stand up from sitting on the floor without help; (9) to stand up from sitting position in a chair without help. Each of the questions has a three point answer scale: 1. easily; 2. with difficulty; 3. unable to do it. Persons answering 'with difficulty' or 'unable to do it' for at least one of the nine questions are considered as having an ADL limitation. We use the term ADL limitation interchangeably with physical functioning limitation. In addition, to capture the number and severity of limitations, we use an ADL score as developed in Stewart et al (1990) and Gertler and Gruber (2003). The ADL score (from 0 to 100) is the normalized score or sum of answers (each ranging from 1 to 3 ) to the nine ADL questions as follows with a minimum of 9 and a maximum of 27 :

ADL Index $=($ Score-MinScore $) /($ MaxScore-MinScore $)$ 
Finally, in order to exploit the data on severity, we divide persons with ADL limitations into two groups. Individuals with Severe ADL limitation include those who are unable to do at least one ADL. Individuals with Moderate ADL limitation include those who have difficulty with at least one ADL (but are able to do all ADLs).

For each of the measures above, we separate the onsets of, and the recoveries from, physical limitations, since we can with the data at hand, investigate the dynamics of health and how it may affect the dynamics of employment. Onsets of physical functioning limitation takes a value 1 if the individual reports physical functioning limitation in the current period and did not report a physical functioning limitation in the previous period, 0 otherwise. Similarly, a recovery from physical functioning limitation takes a value 1 if the individual reports physical functioning limitation in the previous period and no physical functioning limitation in the current period, 0 otherwise. Of course, our data only gives us snapshots in four waves over a 14-year period and thus does not provide a full history of the health of the individual. What we refer to as onsets/recoveries may in fact be episodic or increasing/decreasing physical limitations.

\section{Empirical Strategy}

The theoretical framework underlying this paper is a dynamic model of health production and productivity as in Strauss and Thomas $(1998 ; 2008)$. Our objective here is to isolate the impact of health on employment and hours worked. We implement two specifications - one for employment and one for hours worked. Each of these specifications uses multiple waves of the data and examines the effect of onsets and recoveries from physical functioning limitations on these outcomes.

We use specifications that exploit the longitudinal data to try to address reverse causality, heterogeneity, and measurement error. We start with a first difference specification. It has several advantages. It removes all sources of time-invariant unobservables (e.g. genetic factors) that are likely to be correlated with the measures of health included in the right hand side addressing the 
omitted variables bias problem, assuming that these unobservables enter in an additive way. Further, it also removes the bias arising from the presence of any systematic measurement error fraught in self-reported measures of health. The first-difference specification can be written as follows:

$\Delta Y_{i t}=\beta_{1} \Delta H_{i t}+\beta_{2} \Delta X_{i t}+\delta_{t c}+\Delta u_{i t}$

where $Y_{i t}$ represents the changes in employment outcome, $\Delta H_{i t}$ represents the change in physical functioning and $\beta_{1}$ captures the effect of a change in physical functioning on changes in labor market outcomes. Since changes in employment in response to health changes are typically characterized by substantial heterogeneity, we also include a vector $(\mathrm{X})$ of time varying controls at the individual and household level (Strauss and Thomas 1998). Particularly, we include household size, relationship to the household head (self or spouse), marital status, household location (urban or rural). We also include district time interaction terms $\delta_{t c}$ in the first-difference specification to control for aggregate changes in district-level time-varying labor market conditions. Without district-time interaction terms, the regression may yield biased estimates because of possible correlation between the omitted or unobserved time varying district characteristics and the error term. The district-time interactions allows us to control for any aggregate or covariate risks faced by all individuals in the district, including price changes and aggregate level shocks. $u_{i t}$ is the individual-specific time-varying error term that captures all other time-varying unobservables. $\beta_{1}$

From a policy perspective, it is important differentiate negative changes in health (onsets of, or increases in, physical limitations) from positive changes in health (recoveries from, or reductions in, physical limitation) as the effects of negative and positives changes $\left(\Delta H_{i t}\right)$ in health could be asymmetric. This will be done by focusing separately on negative changes (onsets of limitations) and positive changes (recoveries from limitations). In addition, $\Delta Y_{i t}$ refers to changes 
in employment status for the entire sample and changes in hours worked, conditional on employment. For changes in employment status in the entire sample, we first use a specification where any transition is considered (0: no transition, 1: transition into employment (return to work) and -1: for transition out of employment (employment exit)). Again, because there could be asymmetric effects of health on transitions into and out of employment, we then separate these two types of employment transitions in our dependent variable which takes a value of 1 for, in turn, employment exit and return to work, and 0 otherwise.

Estimates based on equation (1) above will address time-invariant heterogeneity and systematic measurement error. However, combining first differencing with instrumental variables could also help deal with omitted variables bias arising from the presence of time-varying unobservables and random measurement error in the following way:

$\Delta H_{i t}=\gamma_{1} \Delta X_{i t}+\gamma_{2} Z_{i t}+\delta_{t c}+\Delta v_{i t}$

$\Delta y_{i t}=\beta_{1} \Delta \widehat{H}_{i t}+\beta_{2} \Delta X_{i t}+\delta_{t c}+\Delta u_{i t}$

where $\Delta \widehat{H}_{i t}$ is the predicted value from estimating changes in physical functioning on changes in observable individual characteristics $\left(\Delta X_{i t}\right)$ and instrumental variable $\left(Z_{i t}\right)$ in the first stage. Price of health care $\left(Z_{i t}\right)$ would have an impact on the utilization of health services and therefore may be a predictor of observed physical limitations (Strauss and Thomas, 2008). We exploit community-level price data in the IFLS to construct our instrumental variable. We use changes since the prior wave in the square root of the average registration fee for a first visit at the puskesmas (government community health center). This is the price of health care faced by the entire community where each individual lives, and not necessarily paid by individual $i$. We interact the price of health care with age and gender of the individual to get individual level exogenous variation in the changes in physical functioning. 


\section{Results}

\subsection{Descriptive statistics}

The descriptive statistics of the employment outcomes, physical functioning measures, and socioeconomic characteristics for all adults aged 26 to 50 initially surveyed in wave 1 (1993) and then followed through the 1997, 2000 and 2007 waves of the IFLS are presented in Panels A, B, and $\mathrm{C}$ in Table 1 respectively and for each of the four periods. The share of adults employed in our sample increases from $76 \%$ in period 1 to $78 \%$ in period $2,81 \%$ in period 3 , and then decreases in period 4 to $76 \%$. The log of normal hours worked per week decreases from 3.65 to 3.51 . We observe that employment exits since the previous wave are more common in wave 4 , compared to wave $2(5.2 \%)$, while employment entries since the previous wave go down from $7 \%$ in wave 2 to $6 \%$ in wave 4 .

As reported in Panel B, in period 1, $10 \%$ of adults report having at least one ADL limitation. The share of adults with at least one ADL limitation then grows to $20 \%, 26 \%$ and $34 \%$ in periods 2, 3, and 4 respectively. The mean ADL score is $2 \%$ in 1993, and then grows to $2.2 \%$, $3 \%$, and $4.6 \%$ in periods 2,3 , and 4 respectively. During this period, we also observe similar increases in the prevalence rates of both severe and moderate ADL limitations. This deterioration in ADLs is to be expected as this cohort ages. Our goal then is to examine the impact of the increased incidence in the different measures of ADL limitations on employment.

Finally, in Panel C in Table 1, we also present descriptive statistics for the characteristics of the household (including time invariant characteristics) and the instrument. 53\% of the sampled individuals are males. The average size of the household increases from 5.08 in wave 1 to 6.7 members in wave 4 . The share of individuals who are household heads has increased from $58 \%$ in wave 1 to $64 \%$ in wave 4 . The nominal mean registration fee for a first visit to a community health center increased from IDR 398.40 in 1993 to IDR 2,300.55 in 2007. 
Table 2 present rates of onsets of, and recoveries from, physical limitations between waves, for both severe and moderate limitations. For instance, the rate of onset of severe ADL limitation increases from $3.6 \%$ for the $1993-1997$ period, to $6.2 \%$ for the $1997-2000$ period to $9 \%$ for the 2000-2007 period. Rates of recovery also increase over time, for example for moderate limitations, 5\% for 1993-1997 and 12\% for 1997-2000. However, rates of onset increase at a faster pace than those of recovery: for instance the rates of onset and recovery of severe limitations are close in the 1993-1997 period at 3.6\% and 3.4\% respectively, but stand at 9\% and 5\% in 20002007. Overall, Table 2 shows that transitions into and out of ADL limitations are relatively frequent, which justifies and makes it possible to investigate the impact of onsets and recoveries on transitions out of and into employment using this longitudinal data. Together with the prevalence of limitations in Table 1, this shows that in this sample of working-age individuals, physical limitations become more prevalent over time with the increasing onset of lasting limitations and consequently, an assessment of their economic impact is warranted.

\subsection{Impact of Disability on Employment and Hours worked}

Table 3 reports results from the first-difference specification. Regarding employment status, a change in physical limitations is negatively associated with employment status for all physical limitations measures except moderate physical limitation. In other words, a reduction (or increase) in physical functioning is associated with a higher likelihood of employment exit (or entry). For instance, for the severe physical limitation measure, an onset is associated with a 4.6 percentage point increase in the likelihood of exiting employment. For hours worked, a change in any physical limitation is significantly associated with a 6 percentage point decrease in hours worked and this increases to 12 percentage points for severe physical limitations. We also see a large negative effects on the physical limitation score as well.

In Table 4, once again we present results from a first-difference specification to assess the effects of functional limitation onsets on employment exits in Panel A and of recoveries of return 
to work in Panel B. The first column reports coefficients on the entire sample, while the other columns capture the heterogeneous effects across subsamples. For the entire sample, the onset of/recovery from a physical limitation (any, moderate, severe, as per the disability score) is consistently and significantly associated with an increase in the probability of employment exits/return to work respectively. As expected, effects are larger for severe compared to moderate limitations. For instance, the onset of a severe limitation is associated with a 10 percentage point increase in the probability of an employment exit, while a recovery is associated with a 6.4 percentage point increase in the probability of return to work. The effects of onsets of physical limitations on employment exits are relatively larger for males compared to females and in rural areas compared to urban areas. This is not surprising since physical functioning is more likely to be important in rural areas where agricultural income is the primary source of livelihood with a majority of the male population working on the farm. Consistent with these observations, we also find greater effects of onsets of physical limitations for self-employed workers compared to salaried workers. In Panel B, a recovery from a severe limitation leads to a 6.4 percentage point increase in the probability of becoming employed. No significant consistent effect of recoveries is found for the males and female subsamples. The effects of recoveries of physical limitations on return to work hold for urban/rural subsamples, they look marginally, but not likely to be significantly larger in urban areas compared to rural areas.

With regard to hours worked conditional on employment in two waves, in Table 5, for the entire sample, the onset of a physical limitation is associated with a significant reduction in hours worked for all measures except moderate limitation. This result holds for the males and females subsamples, although there is more variation across physical functioning measures. No significant effect is found for the rural subsample, while an effect is found for the urban subsample for three out of four functional limitation measures. Results in Panel B indicate that, a recovery from a physical limitation is not associated with an increase in hours worked among the continuously 
employed for the entire sample and all subsamples. There is thus some asymmetry in the effect of physical limitations on hours worked. A reduction in hours worked seems to be associated with onsets, but there is no significant and consistent change found in hours worked for recoveries.

Tables 6 and 7 give results for the FD-IV specification for employment transitions and hours worked respectively. Our coefficients are larger for the FD-IV specification compared to the FD estimates in Tables 4 and 5. This is similar to the returns to education effects reported in Card $(1995,2001)^{\text {vi }}$. For all the physical limitation measures, the onset of a limitation leads to a significant increase in the transition to non-employment. For instance, the onset of a severe physical limitation leads respectively to a $66 \%$ increase in the probability of transitioning to nonemployment and a $10 \%$ increase in the physical functioning score leads to a $22.9 \%$ increase in the probability of exiting employment. With respect to hours worked, we find that by any measure of physical limitation, the onset of a limitation does not lead to a significant change in hours spent working. The coefficients for all six physical limitation measures are not statistically different from zero for both the onset of, and the recovery from, ADL limitations. We also present results for subsamples for urban and rural areas separately in Tables 6 and 7, and results are overall similar to those in the entire sample for both employment and hours worked. The stratification of results for the self-employed and salaried workers sectors in Table 6 is consistent with the FD results in Table 4. Compared to the self employed, salaried workers are less likely to exit employment given an onset and more likely to return to work given a recovery. Results in Table 7 indicate that hours worked are not significantly affected by onsets and recoveries for selfemployed and salaried workers alike. It should be noted that we cannot further breakdown the results by gender as the instrumental variable (the price of health care services) is interacted with gender.

\subsection{Validity of the instrument}

Results of the first stage regression of Table 6 for employment transitions are in reported in 
Appendix Table A1. The instruments are significantly correlated with the changes in physical limitations. The signs of the coefficients indicate that older persons are more likely to respond to increasing prices of health care services by reporting more physical limitations while males are less likely to do so. This is consistent with earlier research on the price elasticity of health outcomes by gender and age (e.g. Ching (1995)). The first-stage F statistic on the excluded instruments is strong and usually greater than the Stock and Yogo (2002) rule of thumb of 10, suggesting a strong association between the endogenous regressor (physical functioning) and the excluded instrument. We also used the Hansen test of over-identification restrictions. We find that the two IVs cannot be rejected. Result for work hours were similar and are not included in Appendix Table A1.

In addition, our empirical strategy could be invalid if changes in community prices for health care services in fact capture community-wide changes that could simultaneously affect physical limitations and/or employment outcomes such as weather shocks and the construction of new infrastructure. Other recent research (e.g., Genoni 2013) indicates that changes in community prices of health care services are not correlated with natural disasters, the construction of new roads, schools and houses, and the change in the share of households with electricity. Overall, the assessment of the instruments indicate that they are valid, although our analysis is still dependent on unobserved time-varying factors correlated with community prices and employment outcomes having different effects by gender and age.

\subsection{Attrition}

We checked that attrition is not affecting our results: $81 \%$ of individuals in wave 1 could also be followed in waves 2, 3 and 4. These compare to the individual level attrition rates reported in Thomas et. al (2012) who are able to trace approximately $86 \%$ of the individuals in wave 1 by the last wave. Attrition can be a problem only if, firstly, observable factors that result in attrition are correlated with the error term in the specification of interest (1), and secondly, if unobservables 
in the attrition equation are correlated with the unobservables in the empirical specification of interest (Fitzgerald et al 1998). Results of a linear probability model of attrition using wave 1 data of the IFLS are presented in Appendix Table A2. The dependent variable takes the value of 1 if the individual is not followed through the second, third and fourth wave of the IFLS, 0 otherwise. Attrition is regressed on baseline physical, physical limitation score, severe physical limitation and moderate physical limitation as presented in Columns 1-4, Appendix Table A2. Attrition is also regressed on baseline demographic characteristics. Results indicate that attrition is unrelated to the endogenous observables (any physical limitation, score, severe physical limitation and moderate physical limitation) reported in Columns 1-4, Appendix Table A2. The presence of individual specific ability to fight diseases may be related to individuals labor market opportunities resulting in selection related concerns. In addition, variables that are likely to affect both the decision to move and the endogenous covariate, a physical limitation, are also of concern. The preferred FD estimation strategy used above removes all sources of time-invariant unobservable variables addressing these potential sources of attrition bias. A concern for sources of time-varying unobservables affecting both attrition and physical limitations, however, remains.

\section{Discussion}

To our knowledge, this paper is the first study using longitudinal data to estimate the impact of physical disability on labor market outcomes in a LMIC context. Specifically, our goal is to identify the separate impact of both onset and recovery from physical functioning limitation on both changes in employment and hours worked. A number of interesting findings emerge from our analysis. First, the onsets of physical limitations become increasingly prevalent as workers age, and more so than the recoveries from physical limitation. Second, the onset of a physical limitation leads to a higher probability of transitioning out of employment, using both specifications, FD and FD-IV. This result is consistent with those of earlier studies with IV 
specification and cross sectional data (e.g. Schultz et al 1994). Third, we find that recovering from a physical limitation leads to an increase in the probability of return to work. Fourth, with respect to hours worked, we find that the onset of, or the recovery from, physical limitation does not lead to any significant change in hours spent working for those who maintain employment across the waves. Fifth, the onset of a physical limitation, all else constant, has a larger effect on employment exits among the self-employed compared to salaried workers, while a recovery has a smaller effect on return to work among the self employed. We also find that these effects are greater for males and those in rural areas pointing out the importance of physical functioning limitations for the economic livelihoods of the poor who primarily depend on agricultural income for their survival.

Our analysis overall shows that health transitions seem to be significant determinants of transitions out of, but also into, employment. This needs to be kept in the context of our first result that onsets of limitations become relatively more common than recoveries in this cohort of working age individuals. This result suggests that disability measured through physical functioning may be a significant determinant of non-employment for older working age adults in Indonesia, and even more so among self-employed workers compared to salaried workers. Although this could be surprising as the informal sector is typically considered an "easy-entry sector" (Fields 2005), salaried workers are also in a better position, with sick leave for instance, to retain employment, or return to work, given a physical limitation. The difference in results may also come from different working conditions and work-related tasks, with working conditions more risky for physical health and with more physical tasks among the self-employed making it more challenging to continue work or return to work. This result is consistent with self-reported preferences of informal workers in Indonesia among different social security measures (ILO 2012): although preferences were varied, the top two priorities were related to insuring against health problems: " The 1st priority is insurance for accidents at work (mentioned by $36 \%$ of respondents); The 2nd priority is insurance for worker's health (29\%)." 
The findings reported in the paper have important implications for public policy. The impact of physical limitations on employment status and the higher incidence of onset of physical limitations than recoveries found in this paper suggests that some of the disabilities may be longterm. These findings have implications for national safety-net programs and high quality healthcare that improves physical functioning of working-age adults. In the current study, we only observed physical limitations and do not know the reasons for limitations. Therefore, our findings call for studies on the causes of physical limitations.

There may also be a need for rehabilitation services in an LMIC context such as Indonesia to assist people remain employed or return to work following injuries or illnesses. The availability of vocational rehabilitation services in an LMIC context is limited (WHO-World Bank 2011). In some LMICs, there are programs focused on those injured in the workplace (e.g. Malaysia), and in more and more countries, there are community-based rehabilitation programs, the efficacy of which is often not evaluated (WHO-World Bank 2011). In addition, as more LMICs move towards universal health care coverage, results from this paper suggest that if health outcomes improve as a result of health care coverage, there may well be external benefits of health care coverage in terms of improved chances of return-to-work following recoveries.

This paper points out the need for more research on health, disability and employment in LMICs. More research is needed on intra-household substitution in labor market decisions within the family: for instance, do wives work more when husbands get sick or injured, and vice versa? This question has received attention in high-income countries but less so in LMICs. More research is also needed on the dynamics of economic well-being and of health, which has so far been greatly impeded by a dearth of longitudinal data.

The current study has some limitations, specifically with respect to data and health/disability measures. Physical functioning measures as used in this paper are by definition restrictive. This paper focuses on disability measured by physical limitations because the IFLS 
has multiple waves of data with these questions. Broader measures of disability have been developed and tested in various LMICs by the Washington Group on Disability Statistics (Maddans, 2011). Data needs to be collected in LMICs for such broader measures to investigate the economic effects of different types of health problems and disabilities, including cognitive and sensory ones.

\section{References}

Alderman, H., Behrman J.R. and Hoddinott J. (2005). Nutrition, malnutrition and economic growth In: López I Casasnovas G, Rivera B, Currais L, editors. Health and economic growth findings and policy implications Massachusetts: The MIT Press; pp. 169-95.Vol. 30, pp. 98108.

Bowen, W. and T. Finegan (1969). The Economics of Labor Force Participation (Princeton University Press, Princeton, NJ).

Cai, L. K. Mavromaras and Oguzoglu, U. (2014). The effects of health status and health shocks on hours worked. Health Economics, Vol. 23, pp. 516-528.

Card, D. (1995). Earnings, schooling, and ability revisited. In: Polachek, S. (Ed.), Research in Labor Economics, 14. JAI Press.

Card, D. (2001). Estimating the return to schooling: progress on some persistent econometric problems. Econometrica 69 (5), 1127-1160.

Ching, P., 1995. User fees, demand for children's health care and access across income groups: the Philippine case. Soc. Sci. Med. 41, 37e46. 
Currie, J. and Madrian B. (1999). 'Health, Health Insurance and the Labor Market'. In O. Ashenfelter and D. Card (eds.), Handbook of Labor Economics, Vol. 3, pp. 3309-3416.

Dercon, S. and Krishnan P. (2000). In Sickness and in Health: Risk Sharing within Households in Rural Ethiopia, Journal of Political Economy, Vol. 108, pp. 688-727.

Dow et al (1997). Health Care Prices, Health and Labor Outcomes: Experimental Evidence. Labor and Population Program. Working Paper Series 97-01, Rand, Santa Monica CA.

Fields, G. (2005). A guide to multisector labor market models. World Bank Social Protection Discussion Paper series 505. Washington D.C.

García Gómez P. and López Nicolás A. (2006). Health shocks, employment and income in the Spanish labour market. Health Economics . Vol.15, pp. 997-1009.

Gertler, P. and Gruber, J. (2002). Insuring Consumption Against Illness. American Economic Review, Vol. 92, pp. 51-70.

Genoni, M. (2012). Health Shocks and Consumption Smoothing: evidence from Indonesia. Economic Development and Cultural Change, Vol.60, pp. 475-506.

Griliches, Z. and Hausman, J.. (1986). Errors-in-Variables in Panel Data, Journal of Econometrics, Vol. 31, pp. 93-118.

Grimm, M. (2010). Mortality Shocks and Survivors' Consumption Growth, Oxford Bulletin of Economics and Statistics, Vol. 72(2), pp. 146-171.

ILO (2008). Social Security in Indonesia: advancing the development agenda. Geneva: International Labour Organisation.

ILO (2010). Social Security for Informal Economy Workers in Indonesia: looking for flexible and highly targeted programs. Geneva: International Labour Organisation.

Imai, K.S. and You, J. (2014). Poverty dynamics of households in rural China. Oxford Bulletin of Economics and Statistics, Vol. 76 (6), pp. 898-923.

Islam, A. and Maitra P. (2012). Health shocks and consumption smoothing in rural households: Does microcredit have a role to play?, Journal of Development Economics, Vol. 97, pp. 232243.

Kochar, A. (1995). Explaining Household Vulnerability to Idiosyncratic Income Shocks. American Economic Review Papers and Proceedings, Vol. 85(2), pp. 159-164.

Maddans, J.(2011). Measuring disability and monitoring the UN convention on the rights of persons with disabilities: the work of the Washington Group on Disability Statistics. BMC Public Health, Vol.11(Suppl 4: S4).

Mete, C. Ni, H. and Scott, K. (2008). The Impact of Health Shocks on Employment, Earnings, and Household Consumption in Bosnia and Herzegovina in Mete (ed). 
Mete, C. (ed.) (2008). Economic Implications of Chronic Illness and Disability in Eastern Europe and the Former Soviet Union. Washington, D.C.: World Bank.

Meyer, B.D. and Mok, W.K.C. (2013). Disability, Earnings, Income and Consumption. Working paper \#06.10, The Harris School of Public Policy Studies, The University of Chicago.

Mitra, S, Palmer, M., Mont, D. and Groce, N. (2016). Can households cope with health shocks in Vietnam? Health Economics. Vol 25(7).

Mizunoya, S. and Mitra, S. (2013). Is there a Disability Gap in Employment Rates in Developing Countries? World Development Vol. 42; pp.28-43.

Mitra, S., Posarac, A. and Vick**, B. (2013). Disability and Poverty in Developing Countries: a Multidimensional Study. World Development Vol. 41; pp.1-18.

Patel, V. and Kleinman, A. (2003). Poverty and common mental disorders in developing countries. Bulletin of the World Health Organization, Vol. 81(8), pp. 609-614.

Pohl, V. Neilson, C. and Parro, F. (2013). The Effects of health shocks in Chile: Evidence from accidents in Chile, American Economic Review.

Rivera, B. and Currais L. (2005). Individual returns to health in Brazil: A quantile regression analysis. In: López I Casasnovas G, Rivera B, Currais L, editors. Health and economic growth findings and policy implications Massachusetts: The MIT Press; p. 169-95

Thomas, D. and Strauss J. (1997). Health and wages: evidence on men and women in urban Brazil. Journal of Econometrics . Vol. 77, pp.159-86.

Schultz, T. and Tansel, A. (1997). Wage and Labor Supply Effects of Illness in Cote d'Ivoire and Ghana: Instrumental Variable estimates for Days Disabled. Journal of Development Economics, Vol. 53, pp. 251-286.

Schultz, T. (2008). Health Disabilities and Labor Productivity in Russia in 2004 in Mete,C., ed.. Economic Implications of Chronic Illness and Disability in Eastern Europe and the Former Soviet Union. Washington, D.C.: World Bank.

Shrestha, L. (2000). Population aging in developing countries, Health Affairs, Vol. 19 , pp. 20412.

Sparrow, R., Van-De-Poel, E., Hadiwidjaja, G., Yumna, A., Warda, N. \& Suryahadi, A. (2013). Coping with the economic consequences of ill health in Indonesia. Health Economics, DOI: 10.1002/hec.2945.

Stewart, A. and Ware, J. (1992) (eds). Measuring Functioning and Well-Being. The Rand Corporation.

Strauss, J. and Thomas, D. (2008). Health over the life course, in the Handbook of Development Economics, Vol. 4, edited by T. Paul Schultz and John Strauss. 
Strauss, J. and Thomas, D. (1998). Health, nutrition and economic development", Journal of Economic Literature, Vol. 36, pp. 737-782.

Strauss, J., Beegle, K., Sikoki, B., Dwiyanto, A., Herawati, Y. and Witoelar, F. (2004). 'The third wave of the Indonesian Family Life Survey (IFLS3): Overview and field report', WR-144/1NIA/NICHD, the RAND Corporation.

Strauss, J., Beegle, K., Dwiyanto, A., Herawati, Y., Pattinasarany, D., Satriawan, E., Sikoki, B., Sukamdi and Witoelar, F. (2004). Indonesian Living Standards: Before and After the Financial Crisis, the RAND Corporation, Santa Monica, CA.

Smith, J.P., Thomas, D, Frankernberg, E., Beegle K., and Teruel C. (2002). Wages, employment and economic shocks: evidence from Indonesia. Journal of Population Economics, Vol. 15, pp. 161-193.

Thomas, D., Frankenberg, E., Friedman, J., Habicht, J.P., Ingwersen, N., McKelvey, C., Hakimi, M., Jaswadi, Pelto, Gretel, Sikoki, B., Seeman, T., Smith, J. P., Sumantri, C., Suriastini, W. and Wilopo, S. (2006). Causal effect of health on labor market outcomes: Experimental evidence, mimeo.

Trani, J., Jill Kuhlberg, Timothy Cannings \& Dilbal Chakkal (2016): Multidimensional poverty in Afghanistan: who are the poorest of the poor?, Oxford Development Studies, DOI: 10.1080/13600818.2016.1160042.

Trani, J., Parul Bakhshi, Sarah Myer Tlapek, Dominique Lopez \& Fiona Gall (2015): Disability and Poverty in Morocco and Tunisia: A Multidimensional Approach, Journal of Human Development and Capabilities, DOI: 10.1080/19452829.2015.1091808.

Widjaja, M. (2012). Indonesia: in search for a placement-support social protection. ASEAN Economic Bulletin, Vol. 29(3), pp. 184-96.

WHO-World Bank (2011). World Report on Disability. Geneva: World Health Organization.

World Bank (2015) Data bank accessed on July 23 $3^{\text {rd }}, 2015$ at:

http://data.worldbank.org/indicator/SL.UEM.TOTL.ZS?page=3 
Table 1: Descriptive Statistics

\begin{tabular}{|c|c|c|c|c|}
\hline \multirow[b]{2}{*}{ Variables } & \multicolumn{4}{|c|}{ Mean } \\
\hline & 1993 & 1997 & 2000 & 2007 \\
\hline \multicolumn{5}{|l|}{ Panel A: Labor Market Outcomes } \\
\hline Employed (=1 if employed, 0 otherwise) & 0.76 & 0.78 & 0.81 & 0.76 \\
\hline $\begin{array}{l}\text { Hours worked (Log of hours worked } \\
\text { during the last week only if employed) }\end{array}$ & $\begin{array}{c}3.65 \\
(0.77)\end{array}$ & $\begin{array}{c}3.54 \\
(0.95)\end{array}$ & $\begin{array}{c}3.51 \\
(1.01)\end{array}$ & $\begin{array}{c}3.51 \\
(0.91)\end{array}$ \\
\hline $\begin{array}{l}\text { Employment exit ( }=1 \text { if employed in the } \\
\text { last period and not employed in the } \\
\text { current period, } 0 \text { otherwise) }\end{array}$ & NA & 0.052 & 0.048 & 0.11 \\
\hline $\begin{array}{l}\text { Employment entry ( }=1 \text { if not employed in } \\
\text { the last period and employed in the } \\
\text { current period, } 0 \text { otherwise) }\end{array}$ & NA & 0.07 & 0.08 & 0.06 \\
\hline $\begin{array}{l}\text { Panel B: ADL limitations } \\
\text { Any Physical limitation }\end{array}$ & 0.10 & 0.20 & 0.26 & 0.34 \\
\hline Physical limitation score & $\begin{array}{l}0.019 \\
(0.09)\end{array}$ & $\begin{array}{l}0.022 \\
(0.06)\end{array}$ & $\begin{array}{c}0.03 \\
(0.07)\end{array}$ & $\begin{array}{l}0.046 \\
(0.10)\end{array}$ \\
\hline Severe physical limitation & 0.04 & 0.044 & 0.07 & 0.11 \\
\hline Moderate physical limitation & 0.06 & 0.16 & 0.19 & 0.23 \\
\hline
\end{tabular}

Panel C: Demographic and

Socioeconomic Characteristics

Age in Years

26-29 years

30-35 years

36 - 40 years

0.21

0.25

0.23

$41-45$ years

0.17

46 - 50 years

0.14

Male

0.53

Head of the household dummy

0.58

0.60

0.61

0.64

Rural dummy

0.47

0.48

0.48

0.44

Married dummy

0.94

0.92

0.90

0.85

Spouse of the head of the household

0.40

0.38

0.37

0.32

dummy

5.08

5.65

4.92

6.70 


\section{Panel D: Instrument}

Registration fee for first visit at

398.40

631.69

1157.46

2300.55

puskesmas/health center

(166.00)

(436.31)

(609.05)

(4509.83)

Source: Authors' calculations using 1993, 1997, 2000, and 2007 waves of the Indonesian Family

Life Survey. Standard deviations in parentheses. $\mathrm{N}=4,153$ 
Table 2: Rates of onset of, or recovery from, physical limitation between waves

\begin{tabular}{|c|c|c|c|}
\hline & 1993-1997 & 1997-2000 & 2000-2007 \\
\hline Onset of any Physical limitation & 0.16 & 0.17 & 0.22 \\
\hline Onset of severe Physical limitation & 0.036 & 0.062 & 0.09 \\
\hline Onset of moderate physical limitation & 0.14 & 0.15 & 0.20 \\
\hline Onset using the physical limitation score & 0.019 & 0.022 & 0.04 \\
\hline Recovery from any physical limitation & 0.06 & 0.11 & 0.14 \\
\hline Recovery from severe physical limitation & 0.034 & 0.033 & 0.05 \\
\hline Recovery from moderate physical limitation & 0.05 & 0.12 & 0.15 \\
\hline Recovery using the physical score & 0.017 & 0.015 & 0.019 \\
\hline $\begin{array}{l}\text { Source: Authors' calculations using 1993, } 19 \\
\text { Family Life Survey. N=4,153 }\end{array}$ & 2000, and & waves of & ian \\
\hline
\end{tabular}


Table 3: First Difference (FD) Estimates of the Impact of changes in physical functioning on Employment and Hours worked

\section{Employment $+\quad$ Hours worked

FD-OLS FD-OLS

(1)

(2)

\begin{tabular}{lcc}
\hline Any Physical limitation & $-0.012^{* *}$ & $-0.06^{*}$ \\
& $(0.006)$ & $(0.034)$ \\
Severe Physical limitation & $-0.046^{* * *}$ & $-0.12^{*}$ \\
& $(0.011)$ & $(0.064)$ \\
Moderate Physical limitation & 0.006 & -0.025 \\
& $(0.006)$ & $(0.034)$ \\
Physical limitation score & $-0.244^{* * *}$ & $-0.466^{* *}$ \\
& $(0.04)$ & $(0.21)$ \\
\hline
\end{tabular}

+: first-difference in employment is coded as -1 if employed in the previous period and not employed in the current period, 1 if not employed in the previous period and employed in the current period, 0 otherwise. Each estimated coefficient is from a separate regression including time-varying socio-economic controls as listed in Table 1. Standard errors clustered at the individual level in parenthesis. Changes in hours worked presented in Column 2 are conditional upon employment in both periods. *** significant at the $1 \%$ level, ** significant at the $5 \%$ level, *significant at the $10 \%$ level. 
Table 4: First Difference (FD) OLS Estimates of the Impact of Physical Limitations on Employment Exit and Return to Work Transitions

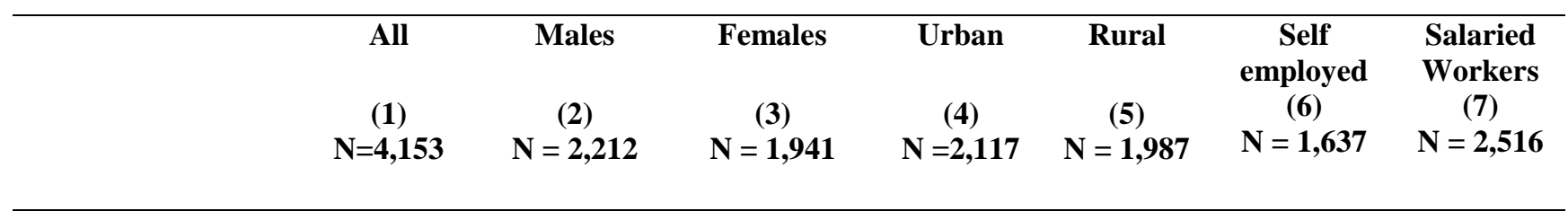

Panel A: Impact of physical limitation onsets on employment exits

\begin{tabular}{|c|c|c|c|c|c|c|c|}
\hline Onset of any & $\begin{array}{c}0.038 * * * \\
(0007)\end{array}$ & $0.055 * * *$ & $\begin{array}{l}0.001 \\
(0.01)\end{array}$ & $\begin{array}{l}0.025 * * \\
(0.010)\end{array}$ & $\begin{array}{c}0.045 * * * \\
(0.011)\end{array}$ & $\begin{array}{c}0.041 * * * \\
(0.013)\end{array}$ & $\begin{array}{c}0.029 * * * \\
(0.009)\end{array}$ \\
\hline Onset based on & $0.61 * * *$ & $0.82 * * *$ & $0.33 * * *$ & $0.477 * * *$ & $0.670 * * *$ & $0.723 * * *$ & $0.485 * * *$ \\
\hline $\begin{array}{l}\text { physical limitation } \\
\text { score }\end{array}$ & $(0.006)$ & $(0.10)$ & $(0.08)$ & $(0.082)$ & $(0.084)$ & $(0.105)$ & $(0.073)$ \\
\hline $\begin{array}{l}\text { Onset of severe } \\
\text { physical limitation }\end{array}$ & $\begin{array}{l}0.10 * * * \\
(0.014)\end{array}$ & $\begin{array}{c}0.18 * * * \\
(0.03)\end{array}$ & $\begin{array}{c}0.044 * * * \\
(0.016)\end{array}$ & $\begin{array}{c}0.086^{* * * *} \\
(0.019)\end{array}$ & $\begin{array}{c}0.115^{* * * *} \\
(0.022)\end{array}$ & $\begin{array}{c}0.135 * * * \\
(0.026)\end{array}$ & $\begin{array}{c}0.080 * * * \\
(0.017)\end{array}$ \\
\hline $\begin{array}{l}\text { Onset of moderate } \\
\text { physical limitation }\end{array}$ & $\begin{array}{c}0.026 * * * \\
(0.007)\end{array}$ & $\begin{array}{c}0.026 * * \\
(0.011)\end{array}$ & $\begin{array}{l}-0.00 \\
(0.01) \\
\end{array}$ & $\begin{array}{c}0.013 \\
(0.010)\end{array}$ & $\begin{array}{l}0.023 * * \\
(0.011)\end{array}$ & $\begin{array}{c}0.021 \\
(0.013)\end{array}$ & $\begin{array}{c}0.015 \\
(0.010)\end{array}$ \\
\hline
\end{tabular}

Panel B: Impact of physical limitation recoveries on return to work

\begin{tabular}{|c|c|c|c|c|c|c|c|}
\hline $\begin{array}{l}\text { Recovery from any } \\
\text { physical limitation }\end{array}$ & $\begin{array}{c}0.040 * * * \\
(0.010)\end{array}$ & $\begin{array}{c}0.015 \\
(0.009)\end{array}$ & $\begin{array}{l}0.011 \\
(0.014)\end{array}$ & $\begin{array}{c}0.042 * * * \\
(0.014)\end{array}$ & $\begin{array}{l}0.028 * * \\
(0.014)\end{array}$ & $\begin{array}{c}0.013 \\
(0.011)\end{array}$ & $\begin{array}{c}0.052 * * * \\
(0.014)\end{array}$ \\
\hline $\begin{array}{l}\text { Recovery from } \\
\text { physical limitation } \\
\text { based on score }\end{array}$ & $\begin{array}{c}0.110 * * * \\
(0.040)\end{array}$ & $\begin{array}{c}0.021 \\
(0.023)\end{array}$ & $-0.009(0.065)$ & $\begin{array}{c}0.170 * * \\
(0.073)\end{array}$ & $\begin{array}{c}0.110 * * * \\
(0.040)\end{array}$ & $\begin{array}{c}0.067 * * \\
(0.033)\end{array}$ & $\begin{array}{c}0.154 * * \\
(0.071)\end{array}$ \\
\hline $\begin{array}{l}\text { Recovery from } \\
\text { severe physical } \\
\text { limitation }\end{array}$ & $\begin{array}{c}0.064 * * * \\
(0.016)\end{array}$ & $\begin{array}{c}0.028 \\
(0.024)\end{array}$ & $\begin{array}{c}0.026 \\
(0.019)\end{array}$ & $\begin{array}{c}0.060 * * * \\
(0.021)\end{array}$ & $\begin{array}{l}0.064 * \\
(0.025)\end{array}$ & $\begin{array}{l}0.032 * \\
(0.019)\end{array}$ & $\begin{array}{c}0.079 * * * \\
(0.022)\end{array}$ \\
\hline $\begin{array}{l}\text { Recovery from } \\
\text { moderate physical } \\
\text { limitation }\end{array}$ & $\begin{array}{c}0.036^{* * * *} \\
(0.010)\end{array}$ & $\begin{array}{c}0.022 * * \\
(0.011)\end{array}$ & $\begin{array}{c}0.002 \\
(0.014)\end{array}$ & $\begin{array}{c}0.032 * * \\
(0.013)\end{array}$ & $\begin{array}{c}0.038 * * * \\
(0.014)\end{array}$ & $\begin{array}{c}0.022 * \\
(0.013)\end{array}$ & $\begin{array}{c}0.040 * * * \\
(0.014)\end{array}$ \\
\hline
\end{tabular}

Notes: Each estimated coefficient is from a separate regression including time-varying socio-economic controls as listed in Table 1. Standard errors clustered at the individual level in parenthesis. **** significant at the $1 \%$ level, ** significant at the $5 \%$ level, *significant at the $10 \%$ level. The rural and urban subsamples include only individuals who remain in rural and urban areas respectively in all four waves. Individuals who move from urban to rural areas (or vice versa) are not included in these subsamples. The self-employed and salaried subsamples are based on the status in wave 1. 
Table 5: FD OLS Estimates of the impact of physical limitation onsets and recoveries on Hours worked

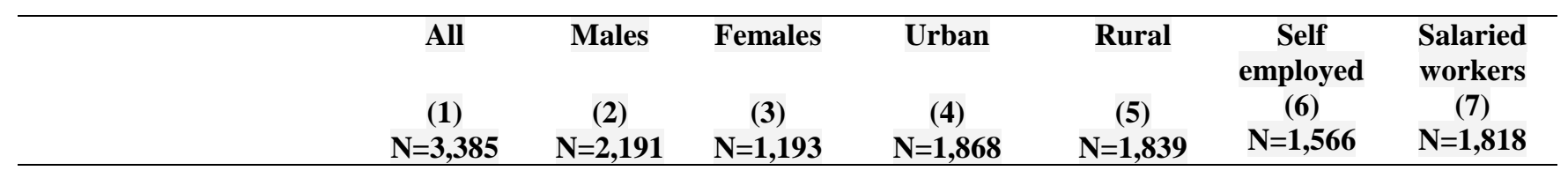

Panel A: Impact of physical limitation onsets on hours worked

\begin{tabular}{lccccccc}
\hline Onset of any physical & $-0.089^{* *}$ & -0.084 & $-0.146^{* *}$ & $-0.154 * *$ & -0.011 & -0.043 & -0.101 \\
limitation & $(0.041))$ & $(0.05)$ & $(0.072)$ & $(0.060)$ & $(0.060)$ & $(0.065)$ & $(0.062)$ \\
Onset of physical score & $-0.904 * * *$ & $-1.487 * * *$ & -0.50 & $-1.535^{* * *}$ & -0.442 & -0.782 & -0.614 \\
& $(0.332)$ & $(0.50)$ & $(0.53)$ & $(0.513)$ & $(0.380)$ & $(0.539)$ & $(0.454)$ \\
Onset of severe physical & $-0.186^{* *}$ & $-0.63 * * *$ & -0.073 & $-0.250^{* *}$ & -0.120 & $-0.286^{* *}$ & -0.034 \\
limitation & $(0.079)$ & $(0.14)$ & $(0.10)$ & $(0.107)$ & $(0.125)$ & $(0.129)$ & $(0.110)$ \\
Onset of moderate & -0.037 & 0.019 & $-0.12^{*}$ & -0.045 & -0.012 & 0.009 & -0.077 \\
physical limitation & $(0.042)$ & $(0.05)$ & $(0.07)$ & $(0.061)$ & $(0.060)$ & $(0.066)$ & $(0.063)$ \\
\hline
\end{tabular}

Panel B: Impact of physical limitation recoveries on hours worked

\begin{tabular}{lccccccc}
\hline Recovery from any & 0.025 & 0.015 & 0.131 & 0.110 & -0.044 & 0.004 & 0.023 \\
limitation & $(0.054)$ & $(0.009)$ & $(0.091)$ & $(0.079)$ & $(0.079)$ & $(0.090)$ & $(0.086)$ \\
Recovery from limitation & 0.249 & 0.021 & 0.503 & $0.793 * *$ & -0.108 & 0.347 & -0.096 \\
based on score & $(0.249)$ & $(0.023)$ & $(0.458)$ & $(0.379)$ & $(0.325)$ & $(0.337)$ & $(0.537)$ \\
Recovery from severe & 0.038 & 0.028 & -0.109 & 0.159 & 0.038 & 0.039 & -0.040 \\
limitation & $(0.090)$ & $(0.024)$ & $(0.116)$ & $(0.124)$ & $(0.090)$ & $(0.144)$ & $(0.136)$ \\
Recovery from moderate & 0.012 & $0.022^{* *}$ & $0.190 * *$ & 0.104 & -0.063 & -0.067 & 0.077 \\
limitation & $(0.055)$ & $(0.011)$ & $(0.088)$ & $(0.081)$ & $(0.079)$ & $(0.094)$ & $(0.086)$ \\
\hline
\end{tabular}

Notes: Changes in hours worked are conditional upon employment in all waves. Notes from Table 4 also apply. 
Table 6: FD-IV estimates of the effect of physical limitation onsets and recoveries on Employment

\begin{tabular}{|c|c|c|c|c|c|}
\hline & $\begin{array}{l}\text { All } \\
\text { (1) }\end{array}$ & $\begin{array}{c}\text { Rural } \\
(2)\end{array}$ & $\begin{array}{l}\text { Urban } \\
\text { (3) }\end{array}$ & $\begin{array}{c}\text { Self } \\
\text { employed } \\
(4)\end{array}$ & $\begin{array}{l}\text { Salaried } \\
\quad(5)\end{array}$ \\
\hline \multicolumn{6}{|c|}{ Panel A: Impact of physical limitation onsets } \\
\hline $\begin{array}{l}\text { Onset of any physical } \\
\text { limitation }\end{array}$ & $\begin{array}{c}0.461 * * * \\
(0.114)\end{array}$ & $\begin{array}{l}0.458 * \\
(0.267)\end{array}$ & $\begin{array}{c}0.334 * * * \\
(0.099)\end{array}$ & $\begin{array}{l}1.132 * * \\
(0.414)\end{array}$ & $\begin{array}{r}0.228 * * \\
(0.107)\end{array}$ \\
\hline $\begin{array}{l}\text { Onset based on physical } \\
\text { limitation score }\end{array}$ & $\begin{array}{c}2.29 * * * \\
(0.536)\end{array}$ & $\begin{array}{l}1.544 * \\
(0.790)\end{array}$ & $\begin{array}{l}1.993 * * * \\
(0.624)\end{array}$ & $\begin{array}{c}4.391 * * * \\
(1.310)\end{array}$ & $\begin{array}{l}1.435^{* *} \\
(0.662)\end{array}$ \\
\hline $\begin{array}{l}\text { Onset of Severe physical } \\
\text { limitation }\end{array}$ & $\begin{array}{l}0.66 * * * \\
(0.158)\end{array}$ & $\begin{array}{c}0.439 * * \\
(0.244)\end{array}$ & $\begin{array}{c}0.570 * * * \\
(0.197)\end{array}$ & $\begin{array}{c}1.102 * * * * \\
(0.232)\end{array}$ & $\begin{array}{l}0.410^{*} \\
(0.209)\end{array}$ \\
\hline $\begin{array}{l}\text { Onset of Moderate physical } \\
\text { limitation }\end{array}$ & $\begin{array}{c}0.473 * * * \\
(0.119)\end{array}$ & $\begin{array}{c}0.517 \\
(0.328)\end{array}$ & $\begin{array}{c}0.333 * * * \\
(0.096)\end{array}$ & $\begin{array}{c}0.927 * * \\
(0.314)\end{array}$ & $\begin{array}{l}0.260 * * \\
(0.123)\end{array}$ \\
\hline
\end{tabular}

Panel B: Impact of Recoveries from physical limitation

\begin{tabular}{|c|c|c|c|c|c|}
\hline $\begin{array}{l}\text { Recovery from any physical } \\
\text { limitation }\end{array}$ & $\begin{array}{c}1.628^{* * * *} \\
(0.290)\end{array}$ & $\begin{array}{c}1.565^{* * * *} \\
(0.470)\end{array}$ & $\begin{array}{c}1.315^{* * *} \\
(0.254)\end{array}$ & $\begin{array}{c}0.801 * * \\
(0.299)\end{array}$ & $\begin{array}{l}1.680^{* * *} \\
(0.295)\end{array}$ \\
\hline $\begin{array}{l}\text { Recovery from physical } \\
\text { limitation based on score }\end{array}$ & $\begin{array}{c}-9.033 * * * \\
(1.370)\end{array}$ & NA & $\begin{array}{c}-6.890^{* * *} \\
(1.153)\end{array}$ & $\begin{array}{c}-4.271 * * * \\
(1.172)\end{array}$ & $\begin{array}{c}-10.588^{* * *} \\
\quad(1.945)\end{array}$ \\
\hline $\begin{array}{l}\text { Recovery from severe physical } \\
\text { limitation }\end{array}$ & $\begin{array}{c}1.972 * * * \\
(0.284)\end{array}$ & NA & $\begin{array}{c}1.529 * * * \\
(0.257)\end{array}$ & $\begin{array}{c}0.835 * * * \\
(0.200)\end{array}$ & $\begin{array}{l}2.780 * * * \\
(0.491)\end{array}$ \\
\hline $\begin{array}{l}\text { Recovery from moderate } \\
\text { physical limitation }\end{array}$ & $\begin{array}{c}1.252 * * * \\
(0.224)\end{array}$ & NA & $\begin{array}{c}1.054 * * * \\
(0.222)\end{array}$ & $\begin{array}{l}0.411 * * \\
(0.134)\end{array}$ & $\begin{array}{c}1.796 * * * \\
(0.355)\end{array}$ \\
\hline
\end{tabular}

Notes and sample sizes as in Table 4 .

NA: Robust standard error could not be estimated 
Table 7: FD-IV estimates of the impact of physical limitation onsets and recoveries on changes in hours worked

\begin{tabular}{|c|c|c|c|c|c|}
\hline & $\begin{array}{l}\text { All } \\
\text { (1) }\end{array}$ & $\begin{array}{l}\text { Rural } \\
(2)\end{array}$ & $\begin{array}{l}\text { Urban } \\
\text { (3) }\end{array}$ & $\begin{array}{c}\text { Self } \\
\text { employed } \\
\text { (4) }\end{array}$ & $\begin{array}{l}\text { Salaried } \\
\quad(5)\end{array}$ \\
\hline \multicolumn{6}{|c|}{ Panel A: Impact of physical limitation onsets } \\
\hline $\begin{array}{l}\text { Onset of any physical } \\
\text { limitation }\end{array}$ & $\begin{array}{c}0.440 \\
(0.649)\end{array}$ & $\begin{array}{c}1.604 \\
(1.834)\end{array}$ & $\begin{array}{c}0.122 \\
(0.662)\end{array}$ & $\begin{array}{c}0.739 \\
(1.321)\end{array}$ & $\begin{array}{c}0.223 \\
(0.708)\end{array}$ \\
\hline $\begin{array}{l}\text { Onset based on physical } \\
\text { limitation score }\end{array}$ & $\begin{array}{c}2.79 \\
(4.59)\end{array}$ & $\begin{array}{c}5.872 \\
(8.280)\end{array}$ & $\begin{array}{l}-0.921 \\
(5.808)\end{array}$ & $\begin{array}{l}1.768 \\
(7.226)\end{array}$ & $\begin{array}{c}4.145 \\
(6.982)\end{array}$ \\
\hline $\begin{array}{l}\text { Onset of Severe physical } \\
\text { limitation }\end{array}$ & $\begin{array}{r}-0.044 \\
(1.242)\end{array}$ & $\begin{array}{c}2.597 \\
(2.100)\end{array}$ & $\begin{array}{l}-0.562 \\
(1.533)\end{array}$ & $\begin{array}{c}0.137 \\
(1.566)\end{array}$ & $\begin{array}{c}0.179 \\
(1.671)\end{array}$ \\
\hline $\begin{array}{l}\text { Onset of Moderate } \\
\text { physical limitation }\end{array}$ & $\begin{array}{c}0.418 \\
(0.637)\end{array}$ & $\begin{array}{c}1.253 \\
(1.801)\end{array}$ & $\begin{array}{c}0.024 \\
(0.694)\end{array}$ & $\begin{array}{c}0.626 \\
(1.085)\end{array}$ & $\begin{array}{c}0.125 \\
(0.786)\end{array}$ \\
\hline
\end{tabular}

Panel B: Impact of Recoveries from physical limitation

\begin{tabular}{lccccc}
\hline $\begin{array}{l}\text { Recovery from any } \\
\text { physical limitation }\end{array}$ & 0.893 & 0.118 & 0.188 & 0.760 & 1.034 \\
& $(0.954)$ & $(1.29)$ & $(1.339)$ & $(1.543)$ & $(1.422)$ \\
$\begin{array}{l}\text { Recovery from physical } \\
\text { limitation based on score }\end{array}$ & -4.067 & -3.842 & -1.106 & -2.867 & -6.673 \\
& $(6.023)$ & $(12.00)$ & $(6.275)$ & $(10.654)$ & $(8.034)$ \\
$\begin{array}{l}\text { Recovery from severe } \\
\text { physical limitation }\end{array}$ & 0.724 & 0.832 & -0.336 & 0.604 & 0.579 \\
& $(1.204)$ & $(1.774)$ & $(1.888)$ & $(1.500)$ & $(2.106)$ \\
$\begin{array}{l}\text { Recovery from moderate } \\
\text { physical limitation }\end{array}$ & 0.308 & 1.003 & -0.379 & 0.300 & 0.449 \\
& $(1.000)$ & $(1.647)$ & $(1.259)$ & $(1.364)$ & $(1.498)$
\end{tabular}

Notes and sample sizes as in Table 4 .

NA: Robust standard error could not be estimated 


\section{Appendix}

Table A1: First-Stage Regression of Table 6 (All)

\begin{tabular}{|c|c|c|c|c|c|c|c|c|}
\hline & $\begin{array}{l}\text { Any Physi } \\
\text { Limitation }\end{array}$ & & $\begin{array}{l}\text { Physical Limitat } \\
\text { Score }\end{array}$ & & $\begin{array}{l}\text { Severe Physical } \\
\text { Limitation }\end{array}$ & & $\begin{array}{l}\text { Moderate Physica } \\
\text { Limitation }\end{array}$ & \\
\hline Panel A: Impact of Onsets of Physic & itation on 1 & Empl & ent Exits & & & & & \\
\hline Change in price of health care $\mathrm{x}$ age & 0.000 & $* * *$ & 0.000 & $* * *$ & 0.000 & $* * *$ & 0.000 & $* *$ \\
\hline Change in price of health care $\mathrm{x}$ male & -0.003 & $* * *$ & -0.001 & $* * *$ & -0.002 & $* * *$ & -0.003 & $* * *$ \\
\hline Household head & -0.057 & $* *$ & -0.032 & $* * *$ & -0.064 & $* * *$ & -0.030 & \\
\hline Spouse of household head & -0.036 & & -0.027 & $* * *$ & -0.067 & $* * *$ & -0.023 & \\
\hline Rural & -0.035 & $*$ & -0.002 & & -0.009 & & -0.030 & $*$ \\
\hline Married & -0.021 & & -0.004 & & -0.016 & & -0.003 & \\
\hline Household size & -0.001 & & 0.001 & $*$ & 0.001 & & -0.004 & $*$ \\
\hline Wave 2 & -0.742 & $* *$ & -0.254 & $* *$ & -0.676 & $* *$ & 0.910 & $* * *$ \\
\hline Wave 3 & -0.455 & & -0.233 & $* *$ & -0.594 & $*$ & 1.099 & $* * *$ \\
\hline Wave 4 & 0.465 & $* *$ & 0.078 & $* * *$ & 0.260 & & 0.450 & $* * *$ \\
\hline$F$ & 9.280 & & 6.920 & & 217.750 & & $1.40 \mathrm{E}+08$ & \\
\hline Panel B: Impact of Recoveries from & cal Limitati & ons 0 & eturn to Work & & & & & \\
\hline Change in price of health care $\mathrm{x}$ age & 0.000 & & 0.000 & & 0.000 & & 0.000 & $* * *$ \\
\hline Change in price of health care $\mathrm{x}$ male & -0.002 & $* * *$ & 0.000 & $* * *$ & -0.001 & $* * *$ & -0.002 & $* * *$ \\
\hline Household head & 0.037 & $* *$ & -0.006 & & -0.008 & & 0.009 & \\
\hline Spouse of household head & 0.007 & & -0.005 & & -0.034 & $*$ & -0.013 & \\
\hline Rural & -0.008 & & -0.001 & & -0.003 & & -0.009 & \\
\hline Married & -0.005 & & 0.005 & & 0.010 & & -0.013 & \\
\hline Household size & -0.004 & $*$ & 0.001 & $*$ & -0.002 & & -0.003 & $*$ \\
\hline Wave 2 & -0.303 & & -0.024 & & 1.193 & $* * *$ & -0.521 & \\
\hline Wave 3 & -0.208 & & -0.028 & & 1.191 & $* * *$ & -0.438 & \\
\hline Wave 4 & -0.150 & & 0.029 & & 0.166 & $* *$ & -0.071 & \\
\hline$F$ & 3769.160 & & 2024.780 & & 9959.340 & & $1.60 \mathrm{E}+09$ & \\
\hline
\end{tabular}

Notes: Each column for each panel gives the results of the first stage regression using a particular health measure. Each cell gives the coefficient of the variable listed in the left column. Household head, spouse of household head, rural residence and household head are first differenced.*** significant at the $1 \%$ level, ** significant at the $5 \%$ level, *significant at the $10 \%$ level. $\mathrm{N}=12,459$ 
Table A2: Determinants of attrition

(1) (2) (3)

\begin{tabular}{ll}
\hline Any physical limitation & -0.018 \\
& $(0.017)$
\end{tabular}

Physical limitation score $-0.058$

$(0.053)$

Severe physical limitation

$-0.035$

(0.026)

Moderate physical limitation

$\begin{array}{cccc} & & & -0.016 \\ 0.001 & 0.001 & 0.001 & (0.019) \\ (0.001) & (0.001) & (0.001) & 0.001 \\ 0.238 & 0.242 & 0.233 & 0.001) \\ (0.214) & (0.217) & (0.212) & (0.217) \\ -0.007 & -0.005 & -0.006 & -0.005 \\ (0.028) & (0.028) & (0.028) & (0.028) \\ 0.004 & 0.005 & 0.004 & 0.004 \\ (0.028) & (0.029) & (0.028) & (0.028) \\ 0.004 & 0.004 & 0.004 & 0.004 \\ (0.003) & (0.003) & (0.003) & (0.003) \\ -0.153 * * * & -0.154 * * * & -0.154 * * * & -0.152 * * * \\ (0.043) & (0.044) & (0.043) & (0.043) \\ 0.091 * * & 0.090^{* *} & 0.090^{* *} & 0.092^{* *} \\ (0.046) & (0.046) & (0.046) & (0.046) \\ 0.110^{* *} & 0.105 * * & 0.103 * * & 0.109 * * \\ (0.052) & (0.051) & (0.050) & (0.052)\end{array}$

Community fixed effects

Yes

Yes

Yes

Yes

Observations

5,103

5,103

5,103

5,103

R-squared

0.231

0.231

0.231

0.231

Robust standard errors in parentheses. $* * * \mathrm{p}<0.01, * * \mathrm{p}<0.05, * \mathrm{p}<0.10$. 


\section{NOTES}

\footnotetext{
${ }^{i}$ Several social protection schemes came into effect towards the end of the study period. Since 2005, a new scheme has been added dealing with health care for the poor program (V. Jamkesmas), an unconditional cash transfer program for the poor or near poor (Bantuan Langsung Tunai) enacted for six months in 2005 and again in 20082009, and a conditional cash transfer program since 2007 (Program Keluarga Harapan) (Widjaja 2012).

${ }^{\text {ii }}$ Strauss et. al (2004) for more details on sample selection and survey instruments.

iii People under age 26 in 1993/94 are not included given that information on physical functioning is not available for this group in 2007: it is available only for persons above age 40 in 2007.

iv We do not use individual earnings as Genoni (2012), with the same dataset, covered this labor market outcome as well as household welfare outcomes.

${ }^{\mathrm{v}}$ Several ADL questions were added to waves 3 and 4 (e.g., to walk for 1 kilometer, to get out of bed) but were not included to have a consistent measure for the four waves. It should also be noted that the order of some ADL questions changed across the waves.

${ }^{\text {vi }}$ IV estimates can exceed OLS estimates for other reasons as well. First, selection bias can push the IV estimates in either direction, greater or less than OLS estimates. Though this can be ruled out in our sample, we find not attrition related selection. Second, those influenced by the instruments are likely to have unusually high returns to health, leading the IV estimates to exceed OLS even when the latter are not influenced by selection bias. (Angrist, 2014)
} 